\title{
Emerging Wake-up Call before next Pandemics as Apart of Medicine and Technology: We terribly need Social and Healthcare Workers
}

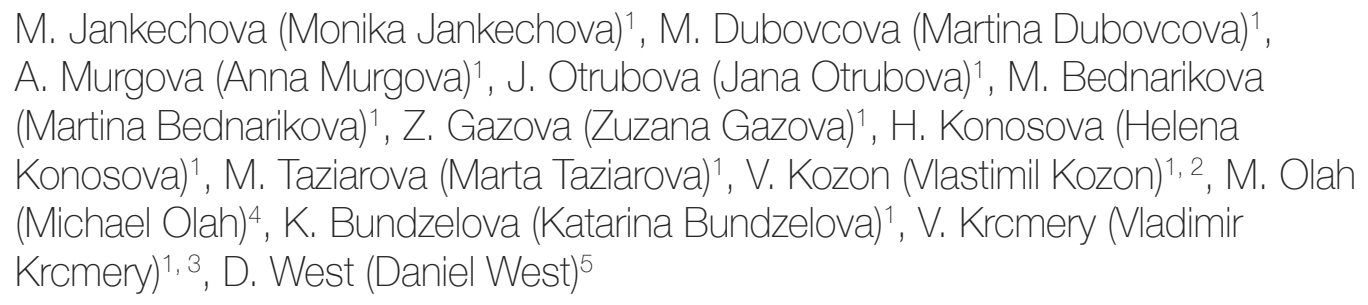

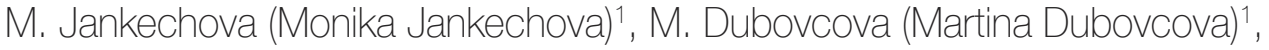
A. Murgova (Anna Murgova)ำ, J. Otrubova (Jana Otrubova)'1 M. Bednarikova

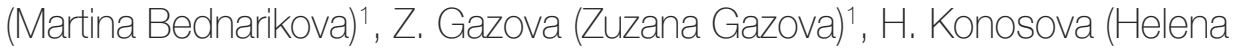
Konosova) $)^{1}$. M. Taziarova (Marta Taziarova)1 ${ }^{1}$, V. Kozon (Vlastimil Kozon)1, 2, M. Olah (Michael Olah) $)^{4}$, K. Bundzelova (Katarina Bundzelova)1, V. Krcmery (Vladimir Kromery) $)^{1,3}$, D. West (Daniel West $)^{5}$

1. St Lesley College Nove Zamky, SK.

2. University General Hospital Vienna, AT.

3. Slovak Medicine University Institute of Tropical Medicine and SEU Dept. of Tropical Diseases Refugee Health Program Lesbos, GR.

4. IGAP and St. John Havlik Institute Vienna, AT.

5. Panuska School of Professional Studies, Scranton, Pennsylvania, USA.

\section{E-mail address:}

jankechova.monika@gmail.com

\section{Reprint address:}

Boris Osmann

SEUC PhD Program in Health Management and Public Health

Pharmacist

Heydeckstrasse 12

39104 Magdeburg

Germany

Source: Clinical Social Work and Health Intervention

Volume: 12

Issue: 3

Pages: $83-85$

Cited references: 12

\section{Reviewers:}

Claus Musss,

Zurich,

Steve Szydlowski

University of Scranton School of Education, USA

\section{Keywords:}

Burnout Syndrome. HCSW.

\section{Publisher:}

International Society of Applied Preventive Medicine i-gap

CSWHI 2021; 12(3): 83 - 85; DOI: 10.22359/cswhi_12_3_14 CC Clinical Social Work and Health Intervention 


\section{Abstract:}

Thousands of healthcare and social workers (HCSW) died or lost their ability to work in their field after Covid pandemics in all three waves, and thousands left their profession due to burnout syndrome. Despite development of vaccines took 618 months and refreshment of old molecules for treatment weeks, many countries paid a very high price for this pandemics not due to lack of medications or ventilator assistance devices but due to the increasing lack of trained HCSW.

\section{Introduction}

Three or four waves of coronavirus pandemics starting in December 2019 taking the next wave (on new epidemic within the pandemic) affected more than 5 million deaths within one year what is more than HIV pandemic within last decade. This appears in early phases despite refreshment of old medicines such as remdesivir, favipiravir within days and discussion and development within 6-12 months of chloroquine, ivermectin and colchicine previously designed MERS and SARS vaccines.

Several military or field hospitals have been built in days in Chine, the USA, the EU, Brazil, India, etc, and ventilation devices, masks were produced in days to weeks. All this was helpful but did not stop the pandemics as we can see in UK, Israel and other countries despite increasing vaccination activity and a high technology healthcare system.

Table 1 Estimates of the need of new HSCW, for 2022-25 in European Union

1. Nurses. 155,000

2. Physicians 35,000

3. ICS specialists, physicians 20,000 or nurses

4. Other paramedics 120,000

5. Medical technology for testing 25,000

6. Public Health for tracing, 32,000 quarantining. etc.

7. Social workers 160,000

\section{What are the reasons we won the battle but not (yet) the war?}

As seen from Table 1, and time framework, one important factor in the everlasting battles against various ID that cannot be organized in days or months - to develop enough qualified HSCW. Despite increasing the number of beds, ventilators, medications, etc. - to educate a social worker serving in senior or mental homes and social service facilities for the elderly; nurses qualified for high technology treatments such as ventilator support, ICU, etc,; mortality in many countries with perfect healthcare system with 10$20 \%$ of GDP investments into healthcare; even more to research of vaccines was unacceptable while in some regions of the EU like North Italy, France, Spain and the UK exceeded 10\%. Education of HCSW take years, from 3 years for a Bachelor Degree in Social Work; nursing full time 4 years part time or specialized; 6-9 years for physicians; including importing technology; building field hospitals; registering active drugs.

We have forgotten, that medicine is not only technology but mainly vocation and art, and chronic infections are not only devastating to patients but also the staff and several suicides as result of burnout syndrome have been reported during the last 18 months of pandemics.

About 50,000 HSCW are leaving their service due to burnout syndrome; chronic fatigue; depression; absence of end-of -the tunnel lights.

\section{Wake up call to educators or governments-investments to human resources education}

Who is responsible that we oriented our battle only to short term roles - how to emergently treat; how to bring more ventilators; build field hospitals. Nobody but all of us. Long term strategies are always at the end of any pandemic response. This is not to criticize excellent work of research and pharmaceutical industry or flexibility in building hospitals or provisional beds. This is only to make wake-up calls to governments and subsequently the academia to prepare any healthcare system to long war - we celebrate 200 years of vaccinations and 100 years of the worst pandemics in Europe "Spanish" influenza, which killed more than died in WWl. We must convince the authorities that human resources are crucial in victory and that it may take years to replace 
those who either died serving the sick as heroes (only in Italy 200 physicians and 600 nurses and paramedics died in 2020 during the first wave. But we must replace or at least rotate those who are leaving or going to leave the healthcare and social facilities. EU estimates the need of 125,000 new HCW, and social workers in next year only to replace those losses. In addition, we have to do long-term investments to rehabilitate those with postcovid or chronic fatigue syndromes to convince them (or foreign or migrant students) to return to their work, since their experience from first waves is extremely valuable. If we start to accept this wake-up call now, please be patient, the first new "fighters against pandemics, to treat, care, trace, test and do all valuable parts of the everlasting battle of next pandemics will not appear earlier than in 3 years. Therefore, starting the education campaign and attracting and opening the doors of our colleges and universities for the students for nursing, social work, medicine and paramedics was the role of yesterday, and latest today.

\section{References}

1. ECDC yearly Report 2000.EU Brussels ECPH 2021,155pp.

2. WHO annual Report, World Health Organization Geneva, 2000, WHO 2021, 552pp.

3. SHAHMAN A, HAEL H, SUVADA J, ULMAN S P, JALILI N AND TOPOLSKA A (2020) Antimalnutrition Projects for children and mothers in areas of armed conflict in Yemen and Autonomous Region - Kurdistan, Iraq. In: Lekarsky obzor, Vol. 69, Issue 5, 2020, ISSN 0457-4214, pp.147-148.

4. KATANA J K, HOLKOVA J, BENCA J, KMIT I, ONDRUSOVA Z, LACA P, GIERTLIOVA D, RUSNAK T, HORVATHOVA E, UTESENA M, HARDY M (2021) HIV mobile clinic as a part of the comprehensive social and public health program in the Malindi Coastal Area. In: Clinical social work and health intervention, Vol.12, Nr. 1, 2021, ISSN 2076-9741/online ISSN 2222-386X/Print, pp. 15-16.

5. EMARY KRW ET AL. (2020) Efficacy of ChAdOx1 nCoV-19 (AZD1222) vaccine against SARS-CoV-2 variant of concern 202012/01 (B.1.1.7): An exploratory analysis of a randomised controlled trial. Lancet 2021
Apr 10; 397:1351.

6. SHIMABUKURO TT ET AL. (2021) Preliminary findings of mRNA Covid-19 vaccine safety in pregnant persons. $N$ Engl $J$ Med 2021 Apr 21; [e-pub].

7. HAVERVALL S ET AL. (2021) Symptoms and functional impairment assessed 8 months after mild COVID-19 among health care workers. JAMA 2021 Apr 7; [e-pub].

8. RECOVERY COLLABORATIVE GROUP (2021) Tocilizumab in patients admitted to hospital with COVID-19 (RECOVERY): A randomised, controlled, open-label, platform trial. Lancet 2021 May 1; 397:1637.

9. LEVINE-TIEFENBRUN M ET AL. (2021) Initial report of decreased SARS-CoV-2 viral load after inoculation with the BNT162b2 vaccine. Nat Med 2021 Mar 29; [e-pub].

10. VASILEIOU E ET AL. (2021) Interim findings from first-dose mass COVID-19 vaccination roll-out and COVID-19 hospital admissions in Scotland: A national prospective cohort study. Lancet 2021 May 1; 397:1646; [e-pub].

11. DORMAN SE ET AL. (2021) Four-month rifapentine regimens with or without moxifloxacin for tuberculosis. N Engl J Med 2021, May, 6, 384:1705.

12. HAJ ALI P, JACKULIKOVA M, SIMONEK M, HEIDER P, TRILISINSKAYA Y, MRAZOVA M, BYDZOVSKY J, LISKOVA J, MIKLOSKOVA M, HUNYADYOVA S, HUNAKOVA L, MIKOLASOVA G AND HARDY M (2020) High colimycin resistance in gramnegative wound pathogens in migrating adolescents in Lesbos and Sames Islands UNHCR refugee centers. In: Lekársky obzor, Vol. 69, Issue 5, 2020, ISSN 0457-4214, pp.152-154. 